NBER WORKING PAPER SERIES

\title{
SPAGHETTI REGIONALISM OR STRATEGIC FOREIGN TRADE: SOME EVIDENCE FOR MEXICO
}

\author{
Alejandro Ibarra-Yunez \\ Working Paper 9692 \\ http://www.nber.org/papers/w9692 \\ NATIONAL BUREAU OF ECONOMIC RESEARCH \\ 1050 Massachusetts Avenue \\ Cambridge, MA 02138 \\ May 2003
}

The author wishes to thank M. Lourdes Dieck for helpful comments on the first version of the report, and an anonymous reviewer. The views expressed herein are those of the authors and not necessarily those of the National Bureau of Economic Research.

(C)2003 by Alejandro Ibarra-Yunez. All rights reserved. Short sections of text not to exceed two paragraphs, may be quoted without explicit permission provided that full credit including Cnotice, is given to the source. 
Spaghetti Regionalism or Strategic Foreign Trade: Some Evidence for Mexico Alejandro Ibarra-Yunez

NBER Working Paper No. 9692

May 2003

JEL No. F1, L1

\title{
$\underline{\text { ABSTRACT }}$
}

After signing ten free trade agreements between 1993 and 2001, Mexico as a world leader in foreign trade policy continues to negotiate with countries such as Japan, Panama, Uruguay or Argentina. Criticism of multiple regional trade agreements (RTAs) arises from a consistency test, but also from the ability of a country to administer them. Mexico's multiple agreements have generally used the principle of NAFTA consistency, after the acceptance that NAFTA became a broader and deeper accord than results of the Uruguay multilateral achievements. An analysis of multiple RTAs is presented, including a game model of equilibrium, along with a political economy approach of why Mexico seeks multiple RTAs as its foreign trade policy.

\author{
Alejandro Ibarra-Yunez \\ Profesor Titular de Economia y Politica Publica \\ EGADE \\ ITESM-Monterrey \\ Ave. Fundadores y Rufino Tamayo \\ Garza-Garcia, NL 66269 \\ MEXICO \\ aibarra@itesm.mx
}




\title{
SPAGHETTI REGIONALISM OR STRATEGIC FOREIGN TRADE: SOME EVIDENCE FOR MEXICO

November 2002; revised version, March 3, 2003, accepted

\begin{abstract}
After signing ten free trade agreements between 1993 and 2001, Mexico as a world leader in foreign trade policy continues to negotiate with countries such as Japan, Panama, Uruguay or Argentina. Criticism of multiple regional trade agreements (RTAs) arises from a consistency test, but also from the ability of a country to administer them. Mexico's multiple agreements have generally used the principle of NAFTA consistency, after the acceptance that NAFTA became a broader and deeper accord than results of the Uruguay multilateral achievements. An analysis of multiple RTAs is presented, including a game model of equilibrium, along with a political economy approach of why Mexico seeks multiple RTAs as its foreign trade policy.
\end{abstract}

JEL classification: F1, L1

KEY WORDS: Mexico, RTAs, political economy, Nash equilibrium.

\section{INTRODUCTION}

The World Trade Organization has accounted for 90 Regional Trade Agreements that have been created among its 136 member countries (formerly GATT contracting parties) since 1995. The figure seems impressive for the dynamism of countries in the world to opt for bilaterals during the past five years (WTO 2001). Besides Europe's activism, Mexico has become a world leader in signing ten RTAs from 1993 to date mainly because it has sought a network of bilateral accords across the world, both with developing countries and also with countries in the developed world.

What are argued reasons for this economy to generate a network of RTAs? A first hypothesis is trade diversification away from increased specialization and dependency from the US market during the past seven years of NAFTA operation. However, trade with its natural partner and the importance of Mexico's market access in North America seems to continue and even deepen in the foreseeable future.

The author wishes to thank Lourdes Dieck and an anonymous reviewer for very useful comments, and participants at the Inter American Seminar in Economics, NBER-ITESM, in Monterrey, Mexico, on November 15, 2002. 
Moreover, trade of intra-industrial nature as has been experienced by NAFTA, has deepened integration among trading and investment partners in key sectors of the North American panorama, to increase the competitive position of the entire North American region that faces apparent open regionalism.

A second line of reasoning is that Mexico's experience with NAFTA has generated a learning curve effect in signing multiple RTAs, mainly Free Trade Agreements with other countries, where most of them contain all the issues and clauses of NAFTA, or what could be called NAFTA-consistency. Aspects such as market access, tariffication, customs procedures, scheduling of liberalization, as well as national treatment/MFN, norms, special treatment of sectors, and dispute resolution mechanisms, are integral part of Mexico's negotiation and signing of RTAs. Moreover, in some agreements, side accords on labor and mainly the environment have also been signed. In such argument, NAFTA becomes a sellable vehicle for trade and investment liberalization, taken strategically or appropriated by Mexico. However, in line with this argument, a limit would exist set by the ability of authorities to administer multiple RTAs.

A third hypothesis is that Mexico's objectives are the political economy ones, where additional to trade and investment liberalization, a rationale of political representation of partners, mainly in Latin America and the Caribbean, is sought in other multilateral negotiations. According to the World Bank (WB 1999), other political objectives are an increased bargaining position of members of a RTA; a strategy of 'being noticed' in multilateral rules of the game; cooperation in areas of government policy making and among incipient multinational companies of developing countries; and commitment to lock-in free market policies inside economies.

A fourth hypothesis is that additional to the learning curve effect, the political economy of generating a network of RTAs is that by seeking bilaterals instead of expanding original RTAs mainly NAFTA, Mexican authorities and economic agents, face economies of scale in negotiating increasing number of RTAs, or to put it in a different context, the cost of NAFTA expansion in political arenas among Mexico, the United States, and Canada, and possibly Chile, is too high both in each country's political 
market, and also in coordinating a regional effort. For such a reason, it seems easier for one of the regional partners to seek individual RTAs. The case that Mexico, the less developed of the NAFTA partners, has been the most active in signing multiple trade agreements could only be circumstantial, but could also imply that a race for strategic trade policy would stay as part of the foreign trade and investment environment in the foreseeable future, with all its implications and worries for trade-dependent and liberalizing economies.

The present essay addresses these issues of the recent strategy by Mexico. It also tries to explain whether the growing number of RTAs has negative or positive effects in members' welfare functions and overall welfare, using a simple Cournot model of market access following Freund (2000). The paper is organized as follows: After briefly presenting evidence of Mexico's network of RTAs and NAFTA parity, a simple stylized model of market access is presented that clarifies the rationale for multiple RTAs as building blocks toward multilateral liberalization. In the fourth part, other economic considerations such as the role of rules of origin, and dispute resolution mechanisms are presented, that give rise to concerns on multiple trade areas. The next part presents noneconomic reasons that could be behind government negotiators in making Mexico a leader in RTA networking. The paper then presents final comments and a conclusion.

\section{MEXICO'S REGIONAL TRADE AREAS}

Trade and investment liberalization in Mexico can be traced back to around 1985, when the country entered GATT and changed its development plans from import substitution and debt-led growth that had become non-viable, to export promotion, the socalled National Program of Industry and Trade, and anti-inflationary measures. Trade-led growth was first experienced with an undervalued currency and a recessionary domestic market, such that implicitly subsidized exports permitted firms to maintain capacity utilization and experiment the first successes in international market penetration. After a new devaluation of the peso and debt renegotiation in 1987 and 1989, respectively, the Mexican economy underwent a period of domestic expansion with macroeconomic discipline and an aligned peso. Trade (exports and imports) became the driver not only for overall growth but also as a means to modernize firms and sectors to access both 
domestic and international markets, and establish price discipline in an economy that had experimented with high inflation rates.

A second period of unilateral trade liberalization deepened tariffication of import quotas and permits, dismantled other barriers to trade (such as financing, reduction of subsidies, and modernization of norms), and opened up the country to increased foreign investment participation by 1989 (Ibarra and Stolp 1990). Overall, the economy experienced massive reforms towards a free trade model of development. The aforementioned period --the Salinas administration-- evolved towards the decision to negotiate bilateral trade agreements. The first approach to negotiate a free trade agreement was between the Salinas and the Bush administrations in 1990. The concept of the RTA was of an open Free Trade Agreement (FTA), where all processes were coherent with GATT XXIV. Bilaterally between Mexico and the US, the negotiated FTA implied the open interest by the US to expand trade, but also to support the free market policies of the Mexican government. For Mexico, the main objective at that point was mainly to expand trade and investment, and also to improve the country's risk assessment and visibility (Feinberg 1997; Andere and Kessel 1992).

The negotiation of NAFTA began by mid 1991 and lasted until November of 1992. Much was followed from the US-Canadian trade deal of previous years, but NAFTA included aspects and procedures with more depth and extension than the USCanadian agreement. After passing congressional approval in 1992, side agreements on labor and the environment, requested by the new Clinton administration took place during 1993, for a launch of NAFTA on January 1, 1994. The negotiation period took 26 months, and involved government officials, advisors, industrial and commerce chambers under a newly formed private sector council (COECE), labor interests, and academics. It was the first experience with such a unique negotiation, not only for Mexico, but also for the US, and for Canada (Hufbauer and Schott 1993).

On its part, Mexico was approached by Chile that had approached the US in tandem. During 1992, negotiations for an Economic Cooperation Agreement (an agreement that did not pretend to liberalize all sectors, such as some agricultural and mining products) moved Mexico and Chile towards an integral deal. It encompassed some unique aspects negotiated in NAFTA, namely a dispute resolution mechanism, 
tariff scheduling, investment liberalization, norms, and rules of origin. The Mexico-Chile agreement was implemented in 1993, when the NAFTA side agreements were negotiated. After these two RTAs, Mexico has embarked in a network of 10 FTAs, plus other trade liberalization participations in diverse regions, such as APEC in Asia, and the Latin American Integration Association (Mexico 2001). Additional to NAFTA, agreements have been signed with Chile, Bolivia, Colombia-Venezuela (G3), Nicaragua, Costa Rica, The European Union (EU15), EFTA, Israel, and Guatemala-El Salvador-Honduras (Northern Triangle). In 2002 and 2003, negotiations are underway for FTAs with Japan and with Argentina. Negotiations began with Panama in 2000 that were then halted. Efforts have also been initiated between Mexico and Uruguay.

Mexican tariffs at implementation of RTAs vary, from a Mexican 4.9\% weighted average inside NAFTA, to $13.4 \%$ in EU. All bilaterals, except for G3 encompassing Colombia and Venezuela, are of wide scope, where minimal exceptions and bracketed sectors exist. In the case of the Northern Triangle agreement, obligations of the Central American partners do not exist to cancel import permits and tariffication. Lists of exceptions prevail in various FTAs, such as G3, all FTAs with Central American partners, and the EU. Most FTAs encompass side agreements on labor and the environment, with exceptions in the Bolivia and Nicaragua deals. In the case of the Northern Triangle, some aspects of the side-type agreements are not spelled out. All FTAs also encompass foreign investment liberalization, norms, and dispute resolution mechanisms similar to NAFTA's chapters 19 and 20, with somewhat lose administrative and procedural obligations of the Mexican partners. Finally, in the case of the European Union, Mexico acquiesced on some European rules of business settlement, exceptions under the European agricultural policies, and a dispute settlement mechanism that is a mix of NAFTA and WTO. Rules of origin and the schedule of liberalization follow NAFTA procedures and method of calculation, but do not necessarily converge. In the case of the European Union, the trade deal was more intricate because it was the first to be negotiated with a group of countries under the EU umbrella, and it encompassed aspects that mixed NAFTA experiences with a heavy load of Community rulings. However, the success in such a case seemed to be to encapsulate trade and investment agreements, to stay separate from other political and social aspects. 
Overall schedules of liberalization were spelled out following the NAFTA benchmark in most RTAs, with full liberalization generally in 10 years. Mexico accepted the asymmetries in levels of development, similar to NAFTA, where de-protection has been substantial on Mexico's part vis a vis other Latin American partners, that would move at a slower pace in their own bilateral liberalization with Mexico. In the case of the EU15, full liberalization will be achieved in 8 years, with a time frame of 3 years for European exports to be granted NAFTA tariff parity.

Other agreements complete the Mexican network of RTAs. Some like the APEC affiliation is of wide regional non-locked in tariff scheduling, while the rest are Complementation Agreements, which could become building blocks towards deep and wide RTAs, but the trend is not conclusive. However, an interest has been made public by the new Fox administration, to further its objective in the Western Hemisphere and other parts of the world. As an example, complementation agreements have been signed in Latin America with Brazil, Argentina, Peru, and Uruguay.

As for the volume of trade, there are arguments that RTAs with integration of sectors and economic activities (some of intra-industrial nature and subcontracting) are sometimes wrongly analyzed with respect to employment generation and displacement. Moreover, it is the generation of scale and scope economies, location factors, and deepening of production chains that international integration through trade should be assessed (Weintraub and Sands 1998). In any case, trade growth is a means of welfare generation and economic efficiency. With Mexico's network of RTAs, its economy has become the eighth most important exporter in the world, with US\$137 billion in 1999, and roughly US\$ 160 billion in 2000. The average annual rate of growth of Mexican exports is $14.8 \%$ between 1990 and 1999, three times faster than the rest of Latin America.

Mexico's specialization in the North American market has increased, from around $52 \%$ of total exports in the mid-eighties, to $71 \%$ in 1994 , and $89.9 \%$ in 1999 , mainly due to NAFTA. Also after NAFTA, Mexico has become the third most important trade partner of the US, surpassing Japan in 1998. Trade with other RTAs has changed unevenly, but overall FTAs have implied upward inflection points in Mexico's trade. For example, trade with the US has grown $135 \%$ between 1994 and 2001, whereas it has 
grown 145\% with Canada (a similar pattern has been evident in Mexican imports except between 1995 and 1996 after the peso devaluation). With Chile, exports grew two fold after its FTA in 1992, mainly in manufactures. With Costa Rica, bilateral trade has grown $262 \%$ between 1995 and 2000, and the figure is a $136 \%$ growth rate in trade with Bolivia. Weaker overall trade growth has been experienced with G3. Growth stood at 37\% with Colombia and 56\% between Venezuela and Mexico, respectively, from 1995 to 2000 (Mexico 2001).

Trade has had a gravitational characteristic, such that the highest percentage of Mexican trade has occurred, additional to the US, with Central America and Canada, leaving trade volume behind in other FTAs. In the case of the EU15, a calculation by the negotiation team during 1999, projected Mexican exports to increase from the present US $\$ 5.2$ billion in 2000 , to around US $\$ 8.8$ billion only in 2003 , when remaining protected sectors will be liberalized. With EFTA or Israel, no projected figures have been calculated. In the Mexican strategy to sign a network of FTAs, little or no official contact was established with former trade partners, especially the US, Canada, or Chile. Informal contact to share opinions however existed. NAFTA parity as a scheme to negotiate might have become sufficiently sound to obviate close contact. A similar environment has existed between the US and Mexico, mainly when the UK government was approached by American officials to explore joining NAFTA (USITC 2000).

\section{A MODEL OF TRADE FROM ALTERNATIVE RTAS}

Tariff rates and asymmetric dynamics in reducing them in a RTA could blockade third country access or generate hold-up, but can also imply an attraction effect to extend an FTA, or the case of access of third countries. Also, superimposed RTAs could create trade diversion or trade suppression if diverse rules of origin exist.

A model of market access can be resembled by a game of production penetration, where rather than price competition of competing producers, market access is directly addressed. A second best linear Cournot model can be applied to explain effects of bilaterals versus addition of members to a RTA. It assumes imperfect competition, a fixed level of tariffs, and substitutability of competing suppliers. Although this stylized second best linear Cournot model cannot explain all aspects of the game of multiple RTAs, and it 
is static, it is useful to explain the optimal number of bilaterals that a country should seek, and whether signing new RTAs will render welfare improvements. It also can show the differences between two RTAs and a new member to an incumbent bilateral.

As a modeling exercise, assume three countries $x, y$, and $z$, where access is made explicit under diverse tariff schemes. A static representation of a Cournot game is useful to map equilibrium options of various tariff schemes. Later we discuss rules of origin and scale economies as additional trade imperfections.

Let $x, y$, and $z$ be the three countries, with inverse demand functions in linear form, as follows:

$$
P^{i}(Q)=1-a Q^{i} \text { where } Q^{i}=q_{x}^{i}+q_{y}^{i}+q_{z}^{i}
$$

where $a$ is a constant, and $q_{j}^{i}$ is quantity produced by country $j$ for country $i$. The model is one of access in volume, or Cournot. The profit function for $\mathrm{X}$ expresses costs of production and a tariff that is positive, as follows:

$$
\begin{aligned}
\pi_{x}^{i} & =q_{x}^{i} P^{i}\left(Q^{i}\right)-c q_{x}^{i}-t_{x}^{i} q_{x}^{i} \\
\pi_{x}^{i} & =q_{x}^{i}\left(1-a q_{x}^{i}-a q_{y}^{i}-a q_{z}^{i}\right)-\left(c+t_{x}^{i}\right) q_{x}^{i}
\end{aligned}
$$

where $c$ is a constant marginal cost of production, and $t$ is a tariff faced by $\mathrm{X}$ in market $i$. An optimum for $\mathrm{X}$ over the quantity in market $i$, then is:

$$
\frac{\partial \pi_{X}^{i}}{\partial q_{X}^{i}}=-a q_{X}^{i}+\left[1-a q_{X}^{i}-a q_{Y}^{i}-a q_{Z}^{i}\right]-\left(c+t_{X}^{i}\right)=0
$$

hence $2 a q_{x}^{i}+a q_{y}^{i}+a q_{z}^{i}=1-c-t_{x}^{i}$

Similarly for countries $\mathrm{Y}$ and $\mathrm{Z}$, the first order conditions are

$$
\begin{aligned}
& 2 a q_{y}^{i}+a q_{x}^{i}+a q_{z}^{i}=1-c-t_{y}^{i} \\
& 2 a q_{z}^{i}+a q_{x}^{i}+a q_{y}^{i}=1-c-t_{z}^{i}
\end{aligned}
$$


Dropping the superscript $i$ for the destination market, if $t_{x}=t_{y}=t_{z}=0$, the solution to the three equation system is $q_{x}=q_{y}=q_{z}=q$, which is the Cournot solution to an oligopoly under identical production costs. Now, moving the parameter a to the right hand side and writing the complete system in matrix form we have:

$$
\left[\begin{array}{lll}
2 & 1 & 1 \\
1 & 2 & 1 \\
1 & 1 & 2
\end{array}\right]\left[\begin{array}{c}
q_{x^{i}} \\
q_{y^{i}} \\
q_{z}
\end{array}\right]=\left[\begin{array}{l}
\frac{1-c-t_{x^{i}}}{a} \\
\frac{1-c-t_{y^{i}}}{a} \\
\frac{1-c-t_{z^{i}}}{a}
\end{array}\right]
$$

And solving for $q_{x}^{i}$ we have:

$$
q_{x}^{i}=\frac{3-C+t_{y}^{i}+t_{z}^{i}-3 t_{x}^{i}}{4 a} ; i=x, y, z
$$

Similarly for Y and Z, the solution gives:

$$
\begin{aligned}
& q_{y}^{i}=\frac{3-C+t_{x}^{i}+t_{z}^{i}-3 t_{y}^{i}}{4 a} ; i=x, y, z \\
& q_{z}^{i}=\frac{3-C+t_{x}^{i}+t_{y}^{i}-3 t_{z}^{i}}{4 a} ; i=x, y, z
\end{aligned}
$$

For example, for country $x$ accessing country $y$, its optimal Cournot quantity will be $q^{y}{ }_{x}=\left[3-c-t^{y}{ }_{z}-3 t^{y}{ }_{x}\right] / 4 a$ such that own tariff $t^{y}{ }_{y}$ is zero. Similarly for the other economy $z$. As for $i=x$, the Cournot quantity would mean domestic production, as follows:

$$
q_{x}^{x}=\frac{3-C+t_{y}^{x}+t_{z}^{x}}{4 a}
$$


With the above equations, one can make some intuitive comments. First, if tariffs to other countries are positive, domestic production increases, as shown in equation (9). If tariffs to third countries increase (equation 7), then sales of one country into another would also increase (relative tariff liberalization).

In a similar fashion and using the demand equation along with equation 7 and the system 8 , total sales in country $i$ are reduced (and prices increase) if tariffs are levied on other countries, hence reducing welfare, as shown by Freund (2000).

The government's welfare function $\mathrm{W}$ of country $X$ is the sum of the consumer and producer surpluses, plus the tariff revenue, as follows:

$$
W=U(Q)-p^{x} Q+\sum_{i=x, y, z}\left(q_{x}^{i} p^{i}-c q_{x}^{i}-t_{x}^{i} q_{x}^{i}\right)+t^{x}{ }_{y} q_{y}^{x}+t_{z}^{x} q_{z}^{x}
$$

Now under a FTA, a set of possibilities can exist: X,Y, can form a FTA leaving Z out, following Yi (1996) of a coalition formation where Z's access to one country (X) or both countries $(X Y)$ is impeded. A second possibility is that after XY form a FTA, Z joins $\mathrm{X}$ in a bilateral, but stays out from $\mathrm{Y}^{\prime}$ 's access (an $\mathrm{X}$ hub and spoke case). A modeling exercise would then be described by the simple game. Tariffs are the behavioral variable to determine quantities. At first countries apply non-zero tariffs, limited by the prohibitive tariff level, and let $I_{i j}$ be an index with a value of one if an FTA is formed and zero otherwise. If tariffs before an RTA are positive but similar across symmetric countries, then $t^{x}{ }_{y}=t_{z}^{x}$, assuming no retaliation, or other countries' tariffs as given. Hence if a country sets a positive tariff in the present exercise, it will be denoted by $t$.

Using equation 10 into 7 and 8, a welfare function is generated by Freund with combinations to show different bilateral alternatives, as follows:

$$
\begin{aligned}
& W=\left[\left(3(1-c)-\left(2-I_{x y}-I_{x z}\right) t\right)^{2}\right] / 32 a+\left[\left(1-c+\left(2-I_{x y}-I_{x z}\right) t\right)^{2}\right] / 16 a \\
& +\left[\left(1-c+\left(1-I_{y z}\right) t-3\left(\left(1-I_{x y}\right) t\right)^{2}\right] / 16 a\right. \\
& +\left[\left(1-c+\left(1-I_{y z}\right) t-3\left(1-I_{x z}\right) t\right)^{2}\right] / 16 a \\
& +\left(2-I_{x y}-I_{x z}\right) t\left[1-c-\left(2+I_{x y}+I_{x z}\right) t\right] / 4 a
\end{aligned}
$$


The first term is the consumer surplus (CS). Note that indexes of RTAs exist such that if $\mathrm{X}$ signs an FTA with $\mathrm{Y}$, but not with $\mathrm{Z}$, the tariff rate directly reduces CS. If two FTAs are signed which are symmetrical then CS is larger than with no FTAs due to formerly setting tariffs for countries $\mathrm{Y}$ and $\mathrm{Z}$ in autarky. The second term stands for profits of firms in the home market, where if two FTAs are signed, a competitive effect, as spelled out by Baldwin and Venables (1995), reduces profits as new firms enter the extended market. The above competitive effect in quantities, does not account for the status quo of market structures ex ante integration, or the change in market structure as the result of entry ex post a FTA implementation. This will be explained in the following section. The third and fourth terms represent country $\mathrm{X}$ 's profits in the $\mathrm{Y}$, and $\mathrm{Z}$ markets, respectively. The final fifth term is tariff revenue.

In the above equation, one can observe the game of reciprocal interaction typical of industrial organization models, and of best response functions followed by a unique Nash equilibrium (Tirole 1995). Indeed, any decision: no FTAs; XY $\mid \mathrm{Z}$ or XZ|Y (symmetry with one FTA); XY+XZ (two FTAs); or an FTA among the three countries $\mathrm{XYZ}$, all imply effects in the five terms spelled out above. Mexico has produced one-onone multiple FTAs. Note that the model only represents the access effect, since it concentrates only on quantities in this stylized static Cournot model.

Again relying on Freund (2000), let us look at the Mexican theoretical results.

First, if countries do not join a RTA, $I_{x y}, I_{x z}$ are zero, for which the optimal tariff is the same as shown above, depending on the cost level $c$. Welfare improvement is then zero. However, welfare clearly improves if X signs one FTA, and increases even further if $\mathrm{X}$ signs two FTAs, where $\mathrm{Y}$ and $\mathrm{Z}$ do not have a coalition or $I_{y z}=0$. This is shown as follows, simplifying for subscripts:

$\mathrm{W}=[\mathrm{t} 6(1-\mathrm{c})-7 \mathrm{t}] / 32 \mathrm{a}$ with one partner, versus $\mathrm{W}=[\mathrm{t} 12(1-\mathrm{c})+8 \mathrm{t}] / 32 \mathrm{a}$ with two partners that do not have coalitions among them

Extending the above to many countries $i, j$, there will be multiple bilaterals or (n1) combinations, as the unique Nash equilibrium in market access as tariffs are dismantled, or a move towards multilateralism. 
Now, if $\mathrm{Y}$ and $\mathrm{Z}$ already have a RTA, $\mathrm{X}$ will be better off signing both one bilateral or two bilaterals (where $I_{y z}=1$ ). Country X welfare will be

$\mathrm{W}=-\mathrm{t}[2(1-\mathrm{c})-\mathrm{t}] / 32 \mathrm{a}$ with one FTA given YZ's bilateral, versus $\mathrm{W}=\mathrm{t}[4(1-\mathrm{c})+4 \mathrm{t}] / 32 \mathrm{a}$ with two FTAs

Again, country $\mathrm{X}$ will be drawn to two bilaterals, as a unique Cournot Nash equilibrium. Note that under the present simple model, welfare clearly improves, by having profits abroad, and the domestic consumer surplus (market access and consumption) outweighs the loss in tariff revenue and domestic profit reduction through more competition and lower domestic output.

Mexico, in its network of FTAs, might be analyzed under this logic, of extending the market for goods and services and promoting growth in partners' firms' profits, even by losing domestic profits and tariff revenue. The same would occur for other new Mexican partners that have been drawn by the Mexican experience with NAFTA. Now, if tariff revenue is a small percentage of government income, this negative effect along with more competition, credibly could be assumed smaller than increased consumer surplus and profits in/ of other markets. Such a finding was presented by Bachrach and Mizrahi (1992), and by Brown, Deardorf, and Stern (1992), but would be an empirical question.

One aspect that emanates from the model above, but seems to be absent from the Mexican government logic of multiple FTAs is that new bilaterals or expansion, affect all parts of the welfare equation. For example, a new FTA will have new effects in reducing domestic profits and tariff revenue, to be counterbalanced by new market access and consumer surplus. Such an effect could make a limit to networking.

Now, what about moving from multiple FTAs towards unifying them in one bloc of, say Latin American partners? If one compares the second welfare functions presented above in the two possible combinations ( $\mathrm{X}$ joins $\mathrm{Y}$, and $\mathrm{Z}$, versus $\mathrm{X}, \mathrm{Y}, \mathrm{Z}$ form a coalition), then the expansion $\mathrm{XYZ}$ clearly dominates the network $\mathrm{XY}$ and $\mathrm{XZ}$. Why is it that Mexico has sought the less than paretian equilibrium? Some other economic explanations have to be sought. 


\section{OTHER ECONOMIC CONSIDERATIONS}

The Cournot model presented above, cannot account for the dynamics of RTAs. An extension to some of the key behavioral and strategic aspects of trade liberalization is presented in this section. A generalized worry is that a RTA of the FTA form may lead to lobbying for protection by members of an agreement, against granting MFN treatment to non-members. In the case of a network of FTAs, deviations from homogeneous tariff and non-tariff reductions across agreements, could be welfare reducing both within blocs and outside them, as many studies of 'endogenous protection' try to show (Grossman and Helpman 1995; Krishna 1998; Panagariya and Findlay 1996). However, the evidence of studies is non-conclusive. Wei and Frankel (1996), for example, show that a RTA can move towards multilateralism by dividing previous opposition forces, whereas Cadot, de Melo, and Olarreaga (1998) stress the usefulness of FTAs when rules of origin are clear and open, and losers are compensated from trade liberalization. Moreover, Adriamananjara (2000) concludes that excluded countries also move strategically. They could become more protectionist, but if a RTA undertakes MFN liberalizations to counteract the reaction, then excluded countries move towards de-protection. The logic of 'divide-conquer-and draw closer,' would be a reason for Mexico's preference for multiple FTAs instead of expansion even if the latter would imply low costs.

Some other key aspects of liberalization --economic reasons - could be extended from the stylized model presented above. First, if the cost functions are adjusted to the existence of economies of scale, then the profits domestically would not always decline as shown in the model, and market access abroad would increase even further from the results of the equations. Welfare could improve in the Cournot model, since the Nash equilibrium would render higher than monopoly quantities at less than monopoly prices. However, the existence of economies of scale would have two negative effects: sunk costs as barriers to entry, and increasing lobbying by 'national champions' of a trade agreement, to be selectively protected. For Smith and Venables (1988), these effects should be weighed against efficiency gains through cost reductions and rationalization of location. 
The evidence from developed countries is non-conclusive. What seems to be apparent is that economies of scale will generate a sort of duality in the production base, where 'national champions' will increasingly integrate both in homogeneous products or what can be taken as intra-industrial trade growth, and also in differentiated products. Now, for differentiated products, the modeled demand equations should include a differentiation parameter, which would make the model more complex, but that would not affect the theoretical logic. Turning now to experiences in the trade front, main Mexican trade products with the US, with Canada, with Chile, and with Venezuela are of the intra-industrial nature. A policy worry by both Mexican and US authorities is how to extend the benefits of NAFTA and other FTAs by Mexico, to disintegrated sectors and firms, and whether compensation policies should be undertaken. That seems to also be the case, when negotiation was underway between Mexico and Nicaragua, MexicoBolivia, and Mexico- Northern Triangle countries. In those FTAs, restrictions to specific sectors meant some deviations from NAFTA parity.

Another key aspect not considered in the stylized model is the case of rules of origin. Rules of origin determine the nationality or regionality of a product to be subject to preferential tariff rates within a FTA. Rules of origin are also fundamental for determining quotas or anti-dumping measures. However, they can serve as a protectionist device, mainly by excluding products originated in non-members, even if they are transformed in a member country. In short, sufficient transformation becomes a cumbersome and subjective measure that could become discriminatory that is not presented in the model. The preferential tariff rate would be plugged into the above equations. However, if different rules of origin exist across the various FTAs because a country such as Mexico has dealt with diverse countries in their levels of development, then trade diversion away from the higher preferential trade partner and into the lower tariffied partner would result. Then asymmetries would exist across the network of FTAs, to affect the results.

Asymmetric equilibrium would not be a problem if all partners face negotiation of RTAs with ex ante low tariffs. For example, using a data set from the World Bank and WTO (2001), countries with which Mexico has signed FTAs show varied levels of MFN tariffs immediately previous to FTA implementation, that range from 12.8 for Venezuela 
(weighted) in 1995, to $4.1 \%$ in the US in 1993. Other weighted tariff rates at the time of FTA implementation were moderate in Colombia (12\%), Bolivia (9.8\%), Chile (10.9\%), and El Salvador (8.5\%), to low in Canada (6.8\% in 1993), Guatemala and Honduras (5.7\%), Costa Rica (4.3\%), and the United States and Nicaragua (4.1\%). In FTAs such as NAFTA, rates have diminished as opposed to MFN tariff rates to the rest of the world. The same has occurred for Chile, and the EU15. Less dynamic tariff dismantling was signed with Bolivia, the G3, and the Northern Triangle of countries. For Costa Rica, tariff reduction has occurred in this economy bilaterally and with the rest of the world. In the case of Mexico, its weighted average tariff stayed at $11.8 \%$ in 1995, but has diminished to $4.1 \%$ in 1999 and is lower with NAFTA partners. This means that Mexico would show the largest difference between its MFN tariff rates and those of its multiple Free Trade Agreements. One has to pinpoint that given its trade dependency with the US, the Mexican's rest of the world average tariff rate shows a $16.2 \%$ in 2000 (nonweighted), according to IADB (2001). For those cases where ex ante tariffs were low, there is overall little suspicion of trade diversion. For the case of G3 and Bolivia, some diversion might have occurred, depending on tariff rates and also the accounting of rules of origin. For the Chile FTA, complementarities in tariff dismantling, and the deep NAFTA parity status, would make one infer little diversion. The case with the EU15 is complex because of exceptions. However, its ex ante tariff rates are low.

Rules of origin affect the welfare functions depicted above, and transmit themselves through demand functions, costs, and even the preferential tariff rates, reducing the welfare improvement through trade diversion, but also via consumption and the very pattern of trade. They also reduce the effectiveness to administer a network of FTAs by Mexico, that makes it a cumbersome management and sets a limit to the network of FTAs. In part this reason is argued that the Mexican strategy could be second best, even if the FTAs are NAFTA compatible. However, the alternative to have a compact overall set of rules of origin for the entire Hemisphere seems implausible at present, additional to the fact that the asymmetric levels of development will not decline to converge on rules of origin.

A final additional economic argument for RTAs is the creation of knowledge capital and investment flows when bilaterals emerge. The agglomeration, knowledge 
creation-specialization, and investment flows, seem to be welfare improving even in the case of trade diversion and asymmetric distribution of gains from bilateral trade. The point has provoked a good set of analytical studies, but has concentrated on the gains from these additional virtuous effects in the less developed area of a RTA. If we follow the approach by Holstrom and Kokko (1997) of contract extension and knowledge specialization, then a network of FTAs beginning with the Mexico-US-Canada NAFTA, would have provoked capital and knowledge creation effects into Mexico, to then be transmitted through the other FTAs mainly with Latin American partners, or a case of capital dissemination. It is not clear how that would operate in the Mexico-EU15 FTA, for example, and other pending agreements. In any case, a study by Ibarra (1998) shows a surge from emerging Mexican multinational corporations, moving part of operations not only to the US border states, but also to other Latin American countries, a signal of complementarities between trade and investment. The signal is only indicative, because data quality and sources are rather imperfect.

How has Mexico approached the process, scope, and framework for its 10 FTAs? As was already emphasized, The Mexican approach has been to seek NAFTA parity in all negotiations. In all cases of negotiating FTAs, experience developed in the first ones by authorities and private sector advisors, has continued to be applied in similar formats of negotiation, in the formation of the same negotiating groups and their objectives, and with NAFTA rulings at hand. In all negotiation cases, the following expert groups have been active: Market Access; Origin and Customs Procedures; Technical and Phytosanitary Norms; Agriculture; Government Procurement; Services; Intellectual Property; Investment; Dispute Settlement; and Illegal Trade Practices. Given different types of partners, the liberalization processes by products and characteristics of rules of origin have not been homogeneous. There are no known studies of the bilateral or regional effects on trade diversion, consumer and market expansion, cost efficiency, scale economies, profitability, and government revenue mix. Hence the results of the model above would depend on the impact on $a, c, t$, and $q$.

\section{THE POLITICAL ECONOMY OF RTAS}


Economic studies of RTAs and specifically of Mexico have concentrated in economic impacts of bilateral trade and investment agreements. Some have used a sectoral descriptive/analytical approach (Andere and Kessel 1992; Garber 1993; Hufbauer and Schott 1995). Others have followed partial equilibrium models or generalizable computational equilibrium ones (Bachrach and Mizrahi 1992; Brown, Deardorf, and Stern 1992; or Roland-Horst, Reinert, and Shiells 1992). From the political economy side, important studies have been created by Weintraub (1995), and much more recently by institutions such as the USITC (See Adriamananjara 1999, 2000; World Bank 2000; and others such a DeRosa 1988; or position papers by Huenemann 2001). For the present paper, this author interviewed key Mexican officials from the Under Secretariat of International Trade Negotiations, to find that little or no focused agreement exists that stresses political reasons for seeking a multiplicity of FTAs by Mexico.

Main non-economic reasons emphasized by a special study on RTAs (World Bank 2000) have been observed to be the following: Security; Bargaining improvements; Being noticed; Policy Coordination; and Policy lock-in. An additional one is conflict evasion with original partners as a reason behind multiple bilaterals. Finally, there is the question of limits of bilateral agreements that could push the agenda towards unifying them under a potential Free Trade Area of the Americas (FTAA).

Security, as a policy choice, was quite a forceful argument when the EU was formed in 1951. Some argumentation also existed between Brazil and Argentina while planning to form MERCOSUR. By increasing trade, intra-regional conflict would decline. For Mexico, however, not such a reasoning existed in the open during NAFTA negotiations, or negotiations with the rest of its RTAs. NAFTA has indeed increased government contact at all levels, between Mexico, Canada, and the US. But it has not necessarily meant conflict reduction in such areas as the environment, labor aspects, or other issues that are important in the partnership but were not part of the trade deal, such as drugs and migration. It is interesting to see that the new Mexican administration is seeking a different approach to cooperation in labor migration, drug trafficking, and judicial coordination with its Northern partners, as well as the emerging approach to contacts in MERCOSUR. Within Mexico, however, the asymmetries in modernization 
by regions, has caused more rather than less political conflict. The case between of Honduras and El Salvador also deserves mention. Even if they are part of the Northern Triangle (along with Guatemala), as defined by Mexico's FTA with them in Central America, they are recently developing a sense of mistrust as partners, because of better credit markets and liquidity in El Salvador, its move towards dollarization, and trade gains distributed unevenly between them.

On the topic of increased bargaining power of members of a RTA with respect to multilateral agencies or third countries, the set of interviews with Mexican government officials showed that there is not an open rationale to pursue the network of FTAs on grounds of Mexico leading the way as a political representative. Given this argument, Mexico would extend its powers more broadly if it represents a set of partners instead of being part of an overall hemispheric area. Indeed, the learning curve that Mexico has developed after NAFTA has made analysts become aware of an international political power. Whether such a power is concentrated in the trade and investment areas, or would extend towards other issues such as political power of the regions, or active representation before multilateral or US stances is yet to be observed. Inside Mexico, there is however one issue that has created divergent approaches to the world. During the transition period towards the inauguration of the Fox administration, a discussion was generated whether the ministry of foreign relations (in charge of foreign diplomacy), or the secretary of the economy (the new name for the former Trade and Industrial Promotion Secretary SECOFI), should be in charge of foreign economic policy. It seems that the discussion was settled in favor of the Secretary of the Economy, where economic reasons would precede foreign policy ones, in relation with Mexico's strategy to expand and deepen its RTAs. So the bargaining power reason to pursue a political agenda is not yet evident, even when a new round of multilateral negotiations begins. The above also relates to the political argument of 'being noticed' internationally, except for the increasing attractiveness of the Western Hemisphere for trade and investment.

Two other political economy reasons might be more clearly present in Mexico's quest for multiple RTAs: Cooperation, and policy lock-in. On cooperation in managing of shared conflicts, resources, and large projects, very little success has characterized Latin America, and overall so-called North- South cooperation. Part of the reason is the 
historical tendency to put all economic and political aspects under the umbrella of signed accords (the LAFTA negative experience during the eighties is a dramatic example). Another reason is that cooperation requires the sharing of the financial and legal costs between partners. Given stark economic and legal asymmetries, political cooperation has only been a marginal idea by Mexican government officials. However, there have been successful examples of political and social cooperation that have surged out of Mexico's FTAs but were not planned within the realm of trade and investment deals. For example, in the case of the Mexico-EU15 FTA, financial cooperation to lagging regions and sectors, as well as cooperation in sharing administrative competence in fiscal, judicial, and financial support to small and medium sized firms was at least discussed deeply during negotiations. Administrative coordination and international benchmarking of government policy decisions is another element of this argument that would impel authorities to prefer a multiplicity of RTAs in favor of extension of existing ones, mainly because political power would stay with the coordinating agency instead of a transnational commission or secretariat.

Whether regulatory change in areas related to international liberalization is more effective and transparent than regulations applied to domestic economic issues is a nonconclusive question that has raised increasing attention by academics, but not by authorities in Mexico. Specifically, a litigious environment exists in international trade in services, such as telecommunications and energy, where regulations to sectors have provoked vocal criticism by authorities in the US, of not compliance to generally accepted regulations in the US viewpoint. But bilaterally dealing with the issue seems preferable to authorities than facing a multilateral litigation, as has been evidenced by Mexico's telecommunications regulator.

Another complementary reason to extend integration via various RTAs has been policy reform commitments, or what is called locking-in. Many aspects of NAFTA and its strategic extension encompass institutional and regulatory commitments and impediments to reversing open economic policies. Now, some officials and business interests have expressed openly that a precondition for FTAs has been pre-commitments by partner governments to maintain a free trade, open capitalism scheme. Some other commitments have been inserted in the trade agreements, whereas a third set of 
commitment mechanisms are more self enforcing and depending upon the expected gains for players in the political game of trade liberalization. Following the game theoretic logic expressed in the stylized model, pre-commitments can work if a mechanism of outof-FTA incentives exists, from partnering governments or multilateral institutions. Some other elements have also been deepened. For example, government procurement and licensing have been modernized; customs procedures and certificates of origin are now transparent and easy to grant; and expropriation has been non-existent (obviously other aspects are more heated, such as trucking, environmental regulations, and telecommunication services as described above).

Pre-commitments by other partners with which Mexico maintains less trade and investment flows are somewhat more diffuse. Any pre-commitment needs auditing, which in being costly, could make the political objective of a RTA less cementing. As a result, free riding on a RTA or violations could emerge. To date, the older FTAs, those with Chile, the G3 one, and the one with Bolivia, have seen little or no evidence of free riding, or that free riding is ineffectual. For this precise reason, the negotiation with the Northern Triangle countries, in being a larger natural market for Mexican interests, moved more litigious. The same has occurred with the US, but not with Canada. Precommitments in short, seem to be evident the more trade and investment importance exists between partners.

Following the other channel of lock-in policy objectives, that of making them part of the FTA, one can give credence to negotiation under NAFTA parity, which at the same time is WTO consistent with all its non-discriminatory commitments in the areas of scheduling of tariff liberalization; tariffication; minimal negative lists; NT/MFN rules of origin; norms and standards; and dispute resolution mechanisms. A strategy depending of the learning curve argument, then reinforces itself with the argument of policy lock-in, to be similar across Mexican partners as a step towards wider regionalism and multilateralism, but cannot make sense of either seeking multiple FTAs or FTA extension. Less clear are explicit aspects in FTAs on services, government procurement, agricultural subsidies, and the rest of issues affecting bilateral relations. For example, Huenemann (2000) has expressed worry that NAFTA pending issues have become low priority in the political economic dialogue between the US and Mexico, and that NAFTA 
has moved to 'automatic pilot.' Lock-in policies to be generalizable from inside the text and implementation of an FTA, then seem to be useful by using the aforementioned NAFTA parity, but are not necessarily binding and credible. Moreover, in being diffuse by Mexico's network of FTAs, commitment policies across partners become more difficult to observe than if NAFTA extension had been successful.

Let us refer briefly to NAFTA compatibility in dispute settlement, spelled out in NAFTA Ch. 19 on antidumping, and 20 on institutions and administrative procedures for dispute resolution. In all ten FTAs, plus the deal with Uruguay, Mexico sought a lock-in procedure for analysis, valuation, measurement of effects and causality, and punishments. For the case of countervailing measures, various institutional settings are spelled out, but are not entirely committed under the clauses. In the case of administrative procedures, mainly the formation of procedural agencies in charge of cases, as well as compulsory panels when disputes are stalled, vary in their legal force, their timing, and their transparency of adjudication. For this reason, hidden actions or information, can give rise to opportunistic tactics among partners. All FTAs include a clause similar to Chapter 19, and some but not all, specify procedural aspects (Chapter 20). For example, the MexicoBolivia FTA does not include obligatory procedures; the one between Mexico and the G3 defines an alternative way arising from the Treaty of Cartagena; the Mexico-EU deal and the one with EFTA, Nicaragua, the Northern Triangle, and Costa Rica, follow lines of procedure under WTO Marrakech treaty. The next step towards a FTAA would not necessarily resolve the variety of in-clause commitments, or would be easier to come about free riding problems.

Finally, policy commitment could arise, not because there is a credible signal before a RTA is signed, neither because aspects of commitment are spelled out as a contract in specific FTAs, but through self enforcing mechanisms and as the result of gains by economic interests in partner countries. For example, a pre-commitment with democracy (such as the one precondition established two years before Mexico begun negotiations with the EU), could be violated if losers from an FTA have market power or can lobby authorities for special protection, or exert political power. If a regional agreement makes a country heavily dependent on trade and investment liberalization, and domestic policy adjustment is visible to the populace as a complementary modernization 
with benefits to everyone, then violating the RTA or deviating from its objectives, could render heavy punishments from abroad (country risk degradation, boycott), or inside the country. But if the effects are concentrated, lock-in policies would not be guaranteed. In short, integration through RTAs would press for lock-in policies if the importance of cross integration increases and benefits are widespread or evident for involved agents.

Are there differences between signing a network of individual FTAs and cementing them into a few RTAs with increasing members? Mexico has followed the first route. It has become a leader in Latin America and elsewhere in signing ten FTAs, plus the ones that will develop in the foreseeable future. The model shows that extension to more countries, rather than extension via multiple FTAs would be welfare enhancing. There are only two reasons for which Mexico has followed an apparent spaghetti of FTAs: It either puts a heavy weight in domestic profit decline due to extended FTA members, or it has used the political economy visibility and lock-in argument step by step with a strategic view.

A last argument to seek multiple FTAs instead of FTA expansion is the case of an easier and less costly negotiation when coordination among former partners is troublesome. Mexico has sought deals in Latin America after 1995 with little or no coordination with the US, Canada, Chile and only with a political paradigm of NAFTA parity as discussed above. Moreover, if criticism of the FTA continues in various levels of the political front, then authorities in Mexico have sought the easiest way towards bilateral liberalizations, even with their efficiency costs.

\section{CONCLUSIONS AND IMPLICATIONS}

Can one say that NAFTA is a success to the point of becoming the model for integrating the hemisphere? Mexico has sought NAFTA parity in its ten FTAs, both in Latin America, but also in Europe, and possibly with Japan in the foreseeable future. What does the analysis of such a strategy show: A spaghetti regionalism or a strategic move towards becoming leader of hemispheric and multilateral integration?

It has been argued that welfare improves by increasing membership into a RTA, if the competitive effect and consumer surplus, outweigh government revenue loss and decline in profits. In the case of economies of scale, cost reduction and rationalization 
minimizes profit loss of domestic interests and makes the results of either multiple RTAs or extension of a RTA non-conclusive. Finally, political economy reasons mainly are apparent in lock-in and administration of bilaterals, but not necessarily in cooperation, bargaining, or visibility in policy making. The reasoning for the network of ten FTAs by Mexico, is that NAFTA parity has been useful and does necessarily make the so-called spaghetti regionalism less a concern than generally advocated, except for disputes that can give rise to free riding. However, commitment is shown not only to depend from the clauses and obligations set forth by a new FTA, but from endogenous commitment if players gain from a deal, as well as an overall pre-commitment by governments, if a strong underlying paradigm of integration emerges, and punishments are enforceable.

Finally, the model shows that the effects on production, profits, and market access under the various alternatives, depend on the partner characteristics. Then a question would be not only if there are limits to the number of RTAs to pursue, but also with whom to seek them.

\section{REFERENCES}

Andere E. and G. Kessel, comp. (1992), México y el Tratado Trilateral de Libre Comercio, México, McGraw-Hill and ITAM.

Andriamananjara, S. (1999), "Regionalism and Incentives for Multilateralism," Office of Economics Working Paper, USITC, No. 99-09-A, September.

Andriamananjara, S. (2000), "Regionalism versus Multilateralism: The Response of the Third Country," Office of Economics Working Paper, USITC, No. 2000-02-C, February.

Bachrach, C. and L. Mizrahi (1992), "The Economic Impact of a Free Trade Agreement between the United States and Mexico: ACGE Analysis, in Economy-wide Modeling of the Economic Implications of a FTA with Mexico and a NAFTA with Mexico and Canada, Pub. No. 2508, Washington, DC. USITC

Baldwin, R.E. and A.J. Venables (1995), "Regional Economic Integration," in Handbook of International Economics, Vol. III, Eds. G. Grossman and K. Rogoff, Amsterdam, Elsevier.

Bolstrom, M. and A. Kokko (1997), "Regional Integration and Foreign Direct Investment," Working Paper Series on Economics and Finance, No. 172, Stockholm, Stockholm School of Economics.

Brown, D.K., A.V. Deardoorf, and R.M. Stern (1992), "A North American Free Trade Agreement: Analytical Issues and a Computational Assessment," The World Economy, Vol. 15 (1): $15-29$.

Cadot, O., J. De Melo, and M. Olarreaga (1998), "Can Bilateralism Ease the Pains of Trade Liberalization," paper presented at CEPR/Venice workshop on globalization, regional integration, and development, Venice, January.

DeRosa, D.A. (1998), "Regional Integration Arrangements: Static Economic Theory, Quantitative Findings, and Policy Guidelines," mimeo, background paper for the World bank Policy Research Project Regionalism and Development, Washington, D.C., August. 
Feinberg R. (1997), Summitry in the Americas, Washington, DC, Institute of International Economics.

Freund, C. L. (2000), "Spaghetti Regionalism," Board of Governors of the Federal Reserve System, International Finance Discussion Papers, Number 680, September.

Garber, P. ed. (1993), The Mexico-US Free Trade Agreement, Cambridge, MA, The MIT Press.

Grossman, G., and E. Helpman (1995), "The Politics of Free Trade Agreements," American Economic Review, Vol. 85 (4), September.

Huenemann J.E. (2001), "The US Trade Relationship with Mexico: Where it has been and where it should go," Policy Papers on the Americas, USTR, January 20.

Hufbauer G.C., and J.J. Schott (1993), NAFTA: An Assessment, Revised Edition, Washington, DC, Institute of International Economics.

Ibarra, A. (1998), "Subcontratación e Inversión Mexicana en Estados Unidos," México, Comercio Exterior, Vol. 48 (4), April, 291-99.

Ibarra, A. and Ch. Stolp (1990), "Exports and Employment Generation in Mexico: A Sectoral Study," Commission for the Study of International Migration and Cooperative Economic Development, No.33

Krishna, P. (1998), "Regionalism and Multilateralism: A Political Economy Approach,"

Mexico (2001), Subsecretaría de Negociaciones Comerciales Internacionales, Secretaría de Economía, database on trade agreements

Panagariya, A. And R. Findlay (1996), "A Political-Economy Analysis of Free Trade Areas and Customs Unions," in Feenstra, R., D. Irvin, and G. Grossman, eds. The Political Economy of Trade Reform, Essays in honor of Jagdish Bhagwati, MIT Press.

Roland-Horst, D.W., K.A. Reinert, and C.R. Shiells (1992), "North American Trade Liberalization and the Role of Nontariff Barriers," in Economy-wide Modelling of the Economic Implications of a FTA with Mexico and a NAFTA with Mexico and Canada," Pub. No. 2508, Washington, D.C., USITC

Smith, A. and A.J. Venables (1988), "Completing the Internal Market in the European Community,” European Economic Review, Vol. 32 (7), 1501-25.

United States International Trade Commission USITC (1997), "Study on the Operation and Effects of the NAFTA," Washington D.C.

United States International Trade Commission USITC (2000), "The Impact on the US Economy of Including the United Kingdom in a Free Trade Arrangement with the United States, Canada, and Mexico, Washington, DC, investigation 332-409, pub. 3339, August.

Wei, S. and J. Frankel (1996), "Can Regional Blocs be a Stepping Stone to Global Free Trade? A Political Economy Analysis," International Review of Economics and Finance, Vol 5 (4), 339-47.

Weintraub, S. (1995), NAFTA at Three: A Progress Report, Washington, D.C., CSIS.

Weintraub, S. and C. Sands (1998), The North American Auto Industry under NAFTA, Washington, DC, CSIS.

World Bank (1999), "World Development Report," Washington, D.C.

World Bank (2000), "Trade Blocs," Policy Research Report, Washington, D.C.

World Trade Organization (2001), International Trade Statistics 2000, on-line at www.wto.org/wto/english/res_e/statis_e.

World Trade Organization (2001), "Regional Integration Agreements," RTA commission, Geneva.

Yi, S. (1996), "Endogenous Formation of Customs Unions under Imperfect Competition: Open Regionalism is Good, “ Journal of International Economics (41) 153-77. 